\title{
Job Satisfaction of Employees in St. Peter's College, Iligan City
}

\author{
PETER DAN P. PUNONGBAYAN \\ ORCID No. 0000-0002-7429-7092 \\ pdp.punongbayan@gmail.com \\ St. Peter's College \\ Iligan City, Philippines
}

\begin{abstract}
In today's competitive environment, it is important to recruit and retain qualified, dynamic, and motivated employees to be viable in the academic world. This study measured the job satisfaction of the employees at St. Peter's College, Iligan City (SPC) using the Job Descriptive Index for the five facets of job satisfaction. These are pay, co-workers, work itself, supervision, and promotion. The job satisfaction of the employees' are measured along the demographic profile variables such as age, marital status, gender, employment description, salary, academic qualification, and tenure. This paper also aimed to measure the employees overall satisfaction with the job using the Job in General Scale. The validated questionnaire used in this study is the Job Descriptive Index and Job in General Scales from Bowling Green University. A descriptive and correlation statistics were used for this study. The study revealed that the SPC employees described that they are generally satisfied with their job although employees from segments of demographic profile describe their satisfaction on the facets of pay, and promotion on the negative. It was found out that there is no significant relationship between the employees' demographic profile and their job satisfaction. The study showed that the employees found dissatisfaction in some facets of the job satisfaction but felt satisfied on the overall job situation. SPC management can use the findings of this study to address important issues on job satisfaction to effectively manage human resource for the continuous improve of the school services.
\end{abstract}

Keywords: Job satisfaction, job descriptive index, job in general, facets of the job satisfaction 


\section{INTRODUCTION}

The pursuit of quality education that is always present in our society begins with the employees of an academic institution, the school officials, faculty, and administrative staff. The success of any college or university in delivering quality education depends primarily on the competence and commitment of its employees. In today's globalization, the importance of the human resource department's function in improving its human resource has become more pronounced in any organization, especially for educational institutions who are the prime producers of human resource needed for employment in every country. The recruitment and retention of qualified, motivated, and proactive employees will determine how successful an academic institution in educating the students.

It is the interest of a school management to measure the job satisfaction level of employees; this includes the department heads, faculty, and staff. Research results have shown that satisfied employees will be more productive and will remain with an employer until retirement. Job satisfaction has been found to be the employee's attitude towards his job; this includes attitude on pay, work itself, co-workers, supervision, and promotion. This study measured the job satisfaction of the employees of St. Peter's College, Iligan City (SPC) along these five facets and further measured the job in general as a whole. This study will be the basis for determining how to address the concerns on job satisfaction among the employees of SPC.

Few would argue that the most valuable resource of any organization is its people. Employees' well-being and their level of satisfaction have been found to impact directly on organizational performance and ultimately organizational success; dissatisfied faculty and staff are unlikely to foster a satisfied student or customer base, and dissatisfied customers directly impact on the bottom line (Bogler \& Nir, 2012).

For the past few decades, employee retention has been of interest to researchers and employers in various fields. To remain competitive in the rapidly expanding global economy and to keep pace with technological advances requires a workforce with robust institutional knowledge; therefore, employee retention is of great importance to business and academic communities (Seegmiller, 2006).

The contemporary educational theory holds that one of the leading causes of inadequate school performance is the inability of schools to adequately staff classrooms with qualified instructors - these staffing problems are primarily due to shortages of instructors, which, in turn, are due to the increases in faculty 
turnover (Ingersoll, 2001).

It is essential to retain qualified employees to uphold institutional standards and to meet the requirements of the Commission on Higher Education (CHED). The quality of education depends on the qualifications and competencies of the faculty. Given the faculty's vital role in influencing education outcomes, the Commission on Higher Education (CHED) requires that teachers must have at least master's degree in the fields in which they teach (CHED, CMO No.40, 2012).

Employees' dissatisfaction can be due to factors that are affecting their job satisfaction. They sometimes feel undervalued, lack opportunities, rifts with supervisors, low pay, and long working hours. However, researches in this field are still going on; it is not yet proven for certain if job satisfaction is related to job performance (Shaikh, Bhutto Qamaruddin Maitlo, 2012).

Investigations about job satisfaction have been conducted in many different areas and for many different occupations. For example, research in the field of law in many Western countries has shown that lawyers are quite satisfied with their working conditions and their job itself, but not satisfied with their salary (Seron, 2007).

\section{FRAMEWORK}

There are different theories on job satisfaction on which this research is anchored on. Each one of the theories has the intention of shedding light and explaining how employees find contentment and fulfillment with their work. The emergence of these theories implies that jobs were perceived as not only a means of earning a living but also as an important extension of a person's identity and happiness. These theories are as follows:

\section{Motivation - Hygiene Theory}

Before developing the two-factor hygiene and motivation theory, Herzberg and his colleagues interviewed two hundred engineers and accountants and asked to recall events which had made them felt excellent or awful about their work, to investigate what caused their satisfaction or dissatisfaction at work. As a result, Herzberg proposed his Motivation-Hygiene Theory or Two-factor Theory of motivation and job satisfaction. 
Herzberg discussed the two theories of motivation as follows:

1. Motivator factors:
a. Achievement
b. Recognition for achievement.
c. Work itself
d. Responsibility for enlarged task
e. Growth and advancement to higher level tasks.

According to this study, employees felt satisfaction from the intrinsic nature of their work and felt dissatisfaction based on the extrinsic environment of their work. If people can get recognition for achievement, be interested in their work, be given responsibility, and they can grow and improve on their job, they will be motivated. The motivators relate to job satisfaction since they are intrinsic in work related elements of promoting job satisfaction through achievement, recognition, the worked itself, responsibility and advancement. The job satisfaction results from motivations based on a need for growth and self-actualization at work. They encourage the employee's growth and development and the major of motivators cause satisfaction with work and an increase in the job performance (Herzberg et al., 1999).

2. Hygiene factors: According to Herzberg et al. (1999) the hygiene factors include:

a. The organization or company its policies and administration.

b. Supervision.

c. Salary, security and status.

d. Relationship with the supervisor.

e. The work environment of conditions.

f. Relationship with employees.

g. Personal life and so on.

Removing these dissatisfiers only prevents employee complaints and the uncertainty of employees' results. These factors are the "hygiene factors". Hygiene factors have a disconcerting effect and lead to employee dissatisfaction. For example, if the employees feel dissatisfaction at work, the service attitudes soon change for the worse and reduce work efficiency. These hygiene factors do not lead to high levels of motivation, but without them minimized; there is 
dissatisfaction. Hygiene factors prevent employees working hard for the company or organization, and as a result, employees only maintain a base level of work. In other words, they are an extrinsic element of work and these factors can have a large influence on employees. Herzberg (1966) suggests the organization can manage the hygiene factors only if they have the understanding of them. On the other hand, encouraging employee growth and promotion are the major motivators that increase satisfaction with the work and improve work performance and raise administration of efficiency.

\section{Hierarchy of Needs Theory}

The "Hierarchy of Needs Theory" was developed by Maslow (1943). According to (McLeod, 2014):

The five needs identified by Maslow are:
a. Physiological needs
b. Safety
c. Love needs
d. Esteem Need
e. Self- actualization

This hierarchy displays as a pyramid. The lowest levels of the pyramid are made up of the most basic needs while the most complex needs are at the top of the pyramid (Kendra, 2015). Needs at the lowest section of the pyramid are fundamental physical requirements including the need for food, water, sleep, and warmth. Once these lower-level needs are met, people can move on to the next level of needs, which are for safety and security. As people advance up the pyramid, needs progressively become more psychological and social. Soon, the need for love, friendship, and intimacy become significant. Further up the pyramid, the need for personal esteem and feelings of accomplishment become the chief concern.

\section{Theory X- Theory Y}

Theory X and Theory Y was an idea devised by Douglas McGregor in his 1960 book "The Human Side of Enterprise." It encapsulated a fundamental distinction between management styles and has formed the basis for much subsequent writing on the subject (Theory $\mathrm{x}$ theory $\mathrm{y}, 2008$ ). The Theory $\mathrm{X}$ shows a deficiency with respect to human behavior, and the motives of the Theory $\mathrm{Y}$ assumes 
employees prefer to work, consider work as a natural thing, have the ability to self-control and show that behavior that actively takes charge of management or responsibility, can exercise self-direction and self-control if they are committed to the goal, have aspirations and potential, can be highly imaginative and creative in order to solve question for the organization, and have the ability to make first-rate decisions. The average person can learn to accept and even seek out responsibility. The manager, instead of control, should replace an autocracy with active to communication and keep a good relationship with employees, satisfy employee needs, and show them how to improve on work accomplishments.

\section{ERG Theory}

In an attempt to line up Maslow's Theory of Needs with empirical studies, Alderfer's ERG Theory elicits three core requirements: Existence, Relatedness, and Growth. This categorization reduction is the result of earlier research on Maslow Hierarchy of Needs that indicates some overlap within the middle levels. According to Alderfer, the needs are not in any order and any desire to fulfill a need can be activated at any point. Alderfer (1972) simplified and extended "Maslow's Hierarchy of Needs" into a shorter set of three needs: Existence, Relatedness, and Growth.

\section{Equity Theory}

Equity theory of motivation, developed in the early 1960's by J. Stacey Adams, recognizes that motivation can be affected by an individual's perception of fair treatment in social exchanges (Redmond, 2015). This theory states that people not only care for themselves but also care for about the comparison with others, think about the equity level from the main job inputs elements of effort, and job outcomes and rewards so that they can get balance or all parts create fairness in the organization work environment.

1. Job inputs include wisdom, education, skill, time, commitment, ability, enthusiasm, loyalty, adaptability and so on.

2. Job outcomes include pay, salary, bonus, and commissions, benefits, pension arrangements, intangibles of reputation, recognition, praise, responsibility, training, development, achievements, promotions, and so on. Adams (1965) felt creating equity can challenge employees to action if they feel an inequitable situation exists it will lead to negative influences, thereby, a leader must share 
in work assignment and pay, salary, equity of benefits, and justice evaluation of performance, to establish equitable decisions.

All these theories frame the concept of job satisfaction and the variables presented in the conceptual framework:

\begin{tabular}{|c|c|}
\hline $\begin{array}{l}\text { INDEPENDENT } \\
\text { VARIABLES } \\
\text { Demographic Factors } \\
\text { 1. Age } \\
\text { 2. Gender } \\
\text { 3. Marital Status } \\
\text { 4. Educational } \\
\text { Qualification } \\
\text { 5. Employment } \\
\text { Classification } \\
\text { 6. Employment Status } \\
\text { 7. Salary Rate } \\
\text { 8. Length of Service }\end{array}$ & $\begin{array}{l}\text { DEPENDENT VARIABLES } \\
\text { Job Satisfaction } \\
\text { 1. Job Descriptive Index (JDI): } \\
\text { Work-Itself } \\
\text { Pay } \\
\quad \text { Promotion } \\
\text { Supervision } \\
\text { Co-worker } \\
\text { 2. Job in general (JIG) }\end{array}$ \\
\hline
\end{tabular}

Figure 1. Conceptual Framework

In this study, the dependent variable is the job satisfaction of the employees of St. Peter's College, Iligan City. This was measured by the Job Descriptive Index (JDI) for work itself, pay, promotion, supervision, co-worker and the Job In General (JIG). The independent variables are composed of the demographic profile of the employees; these are age, gender marital status, educational qualification, employment classification, employment status, salary rate, the length of service, and a number of children. This study tried to determine the relationship and difference between the variables based on the responses of the employees.

Herzberg (1957) identified several characteristics of satisfied/dissatisfied workers. They indicate that morale is up when people are new to their jobs. As years go by, morale decreases and remains relatively at a low point until workers are in their late 20's or early 30's. After this phase, job satisfaction of workers goes up as years continue to go by until the later part of their careers. The same inclination is found regarding a worker's length of service. Workers begin with 
high morale then job satisfaction goes down after a few months of work and remains at a low point for a couple of years. Then as the length of service increases, job satisfaction levels have a tendency to rise. Regarding gender, there are no conclusive studies about the differences in male and female and job satisfaction. Some studies reviewed by Herzberg et al. (1957) show that females are more satisfied with their jobs while others indicate that males are more satisfied.

Studies were conducted on educational level and job satisfaction. Some studies show that teachers or employees with higher educational level tend to me more satisfied with their job. This may be because the higher the educational level of a person the higher is his pay, chances of promotion, and is given more freedom on how to perform his job compared to employees with lower educational attainment. Other studies, however, indicated that employees with high educational attainment have low job satisfaction.

According to Zickar (n.d.):

The Job Descriptive Index is designed to measure employees' satisfaction with their jobs. The JDI is a "facet" measure of job satisfaction, meaning that participants are asked to think about specific facets of their job and rate their satisfaction with those specific facets. The JDI is comprised of five facets, including satisfaction with: coworkers, the work itself, pay, opportunities for promotion, and supervision.

The Job In General is also designed to measure employees' satisfaction with their jobs. The JIG is a measure of global satisfaction, meaning that participants are asked to think about how satisfied they are with their job in a broad, overall sense.

\section{OBJECTIVES OF THE STUDY}

This study aimed to determine the influence of the demographic factors of the employees of St. Peter's College on their job satisfaction along the different facets of job situation measured using the Job Descriptive Index (JDI) and Job in General (JIG) scales.

Specifically, it aimed to: 1) determine the demographic profile of the respondents according to age, gender, length of service, educational qualification, marital status, employment status, employment classification, salary rate, and number of children; 2) determine the job satisfaction of the employees in relation to work itself, pay, promotion, supervision, co-workers, and the job in general; 
3) determine if there is a significant relationship between the employees' profile and their job satisfaction as measured by the Job Descriptive Index; 4) determine if there is a significant relationship between the employees' profile and their job satisfaction as measured by the Job In General; 5) determine if there is a significant difference between the demographic profile of the employees and their job satisfaction as measured by the Job Descriptive Index; \& 6) determine if there is a significant difference between the demographic profile of the employees and their job satisfaction as measured by the Job In General.

\section{Hypotheses}

The following hypotheses are tested at .05 level of significance:

$\mathbf{H}_{01}$ : There is no significant relationship between the employees' demographic profile and their job satisfaction as measured by the Job Descriptive Index.

$\mathbf{H}_{\mathbf{0 2}}$ : There is no significant relationship between the employees' demographic profile and their job satisfaction as measured by the Job In General.

$\mathbf{H}_{03}$ : There is no significant mean difference between the employees' demographic profile and their job satisfaction as measured by the Job Descriptive Index.

$\mathbf{H}_{03}$ : There is no significant mean difference between the employees' demographic profile and their job satisfaction as measured by the Job In General.

\section{METHODOLOGY}

\section{Research Setting}

The study was conducted at St. Peter's College located along Sabayle Street, Iligan City. This institution is a non-stock, non-profit, non-sectarian school that offers 25 academic programs in Basic Education, Tertiary Education, and Graduate Studies. Some academic programs are accredited by Philippine Association of Colleges and Universities Commission on Accreditation (PACUCOA). This institution has 154 employees and has been serving the community since 1952 .

\section{Research Design}

This study employed a descriptive and correlational research design. It is descriptive because it provides descriptive information of the demographic nature of the respondents and correlational because it attempts to estimate the 
relationship between the respondents' demographic profile and job satisfaction as measured by the Job Descriptive Index and Job In General.

\section{Respondents and Sampling Procedure}

Purposive sampling was used in this project study. The researcher chose to include in this study only the full-time employees, both regular and probationary. This study excluded the part-time employees as well as the subcontracted employees. From a total of 154 employees for School Year 2015-2016, all 97 full-time employees were the respondents aware 80 employees participated and submitted back the survey forms. However, only 70 of the survey responses were valid based on the JDI guideline.

\section{Research Instruments}

A standardized questionnaire was used in this study. A job satisfaction survey instrument was purchased online from the Job Descriptive Index Office of the Department of Psychology, Bowling Green State University, USA (https://www. bgsu.edu/arts-and-sciences/psychology/services/job-descriptive-Index.html).

According to the Job Descriptive Index (JDI):

The Job Descriptive Index is designed to measure employees' satisfaction with their jobs. The JDI is a facetmeasure of job satisfaction, meaning that participants are asked to think about specific facets of their job and rate their satisfaction with those specific facets. The JDI is comprised of five facets, including satisfaction with: coworkers, the work itself, pay, opportunities for promotion, and supervision.

The Job In General is also designed to measure employees' satisfaction with their jobs. The JIG is a measure of global satisfaction, meaning that participants are asked to think about how satisfied they are with their job in a broad, overall sense.

The survey instrument showed the five facets namely work itself, pay, promotion, supervisor, and coworkers; also included is the job in general (JIG). Instructions on how to answer the survey instrument are included in the questionnaire as well as the descriptions of the different facets and JIG. Phrases or adjectives were assigned describing positively or negatively each facet and JIG. Respondents were to write down "Y" for yes, if the phrase or adjective describes the facet or JIG and "N" for no if the phrase or adjective does not describe 
the facet or JIG. Respondents can write down "?" if they are undecided. The researcher designed the demographic profile survey instrument.

\section{Research Protocol}

The researcher secured permission from the Dean of the School of Graduate Studies to conduct the job satisfaction study and an approval was obtained from the President of St. Peter's College, Iligan City to conduct a survey using questionnaires on the school's full-time employees' opinion on job satisfaction. A letter of consent was given to all the respondents asking for their voluntary participation in the study and also explaining the purpose of the survey.

\section{Data Gathering Procedure}

The data for this study were gathered using the demographic profile questionnaire and the JDI survey questionnaire. The questionnaires were distributed last October 24, 2015 by the researcher with the assistance of the HR Officer. The Deans and Department Heads offered assistance by volunteering to distribute and retrieve the questionnaires to and from the faculty or staff that were not readily available when the researcher was making the distribution rounds. The researcher emphasized the anonymity of the survey respondents; it was reiterated not to write down their names or initials to encourage impartial responses.

Respondents who preferred to answer the survey questionnaires right away finished in 15 minutes or less. The majority of the respondents, however, chose to complete the survey at a later date. The questionnaires not collected by the researcher were submitted to the Department Heads. All survey questionnaires collated from the different offices within one week after the first day of survey questionnaire distribution are encoded in the SPSS. The majority of the respondents completed and returned the survey instruments while about $14 \%$ did not return or give back the survey questionnaires to the researcher.

The data gathered were assigned values to be able to measure the responses. The following JDI guideline is as follows: replace 1 for "Y", replace 2 for "N", and replace 3 for "?". Respondents who partially answered the demographic profile questionnaires are not considered for statistical analysis. The guideline for the cleaning of data is as follows:

- JDI questionnaires with more than two (2) no answers for pay, and promotion was not considered valid.

- JDI questionnaires with more than three (3) no answers for work itself, supervision, promotion, and job in general were also not considered valid. 


\section{Statistical Techniques}

The frequency and percentages were derived from the demographic profile data to describe the profile of the respondents. The statistical measure, mean, was used to analyze the job satisfaction in relation to work itself, pay, promotion, supervision, and coworker as well as the job in general. The standard deviation was also derived for the estimate relative to the dispersion of the responses.

To determine the relationship between the independent and dependent variables, if any existed, a non-parametric test using Chi- Square (Fisher's Exact) was employed. The difference between the means of the job satisfaction of the employees along the demographic profile (age, length of service, educational qualification, marital status, employment classification, salary rate and the number of children) and the JDI and JIG are conducted using One-way-ANOVA test of significance. For demographic profile which has two categories like gender and employment status, a t-test was employed.

The SPSS software is used for statistical analysis. The JDI survey instruments also provided an SPSS syntax guide. The results were rounded-off based on the following rule (Vance, 1984): If the first digit discarded is 5,6,7,8, or 9, increase the last digit kept by 1 . If the first digit discarded is $0,1,2,3$, or 4 , do not change the last digit kept. The following scale is used for the interpretation of job satisfaction among employees: 1.0 to 1.49 for Satisfied, 1.5 to 2.0 and up for Not Satisfied. The closer the mean value to one (1), the higher is the degree of satisfaction. The closer the mean value to two (2), the higher is the degree of dissatisfaction.

\section{RESULTS AND DISCUSSION}

Objective 1. To determine the demographic profile of the respondents according to age, gender, length of service, educational qualification, marital status, employment status, employment classification, salary rate, and the number of children

Table 1. Demographic Profile according to Age

\begin{tabular}{|c|c|c|}
\hline Age Category & Frequency & Percentage \\
\hline $21-29$ years old & 23 & $33 \%$ \\
\hline $30-39$ years old & 18 & $26 \%$ \\
\hline $40-49$ years old & 16 & $23 \%$ \\
\hline $50-59$ years old & 7 & $10 \%$ \\
\hline $60-69$ years old & 6 & $9 \%$ \\
\hline Total & 70 & $100 \%$ \\
\hline
\end{tabular}


At the start of the study, all full-time employees were categorized according to age. Thereby, the total sample was divided into five categories. Table 1 shows that the majority of the sample population is quite young, 23 of the respondents or $33 \%$ are between $21-29$ years old, 26\% are between 30-39 years old. While 23\% belong to the $40-49$ years old bracket, and 7 of the respondents or $10.3 \%$ are nearing the optional retirement age of 60 years old. Lastly, the respondents from the60-69 year's old bracket composed 9\% of the sample population.

Table 2. Demographic Profile according to Gender

\begin{tabular}{|c|c|c|}
\hline Gender Category & Frequency & Percentage \\
\hline Male & 19 & $27 \%$ \\
\hline Female & 51 & $73 \%$ \\
\hline Total & 70 & $100 \%$ \\
\hline
\end{tabular}

The sample consists of 70 full-time employees. Out of the sample, only 19 employees are male, this represents $27 \%$ of the sample population. The rest belong to the female category, and they correspond to the majority of the respondents, making up $73 \%$ of the sample.

Table 3. Demographic Profile according to Length of Service

\begin{tabular}{|c|c|c|}
\hline Length of Service & Frequency & Percentage \\
\hline below 1 year & 15 & $21 \%$ \\
\hline $1-5$ years & 27 & $39 \%$ \\
\hline $6-10$ years & 7 & $10 \%$ \\
\hline $11-15$ years & 6 & $9 \%$ \\
\hline $16-20$ years & 8 & $11 \%$ \\
\hline 21 years -longer & 7 & $10 \%$ \\
\hline Total & 70 & $100 \%$ \\
\hline
\end{tabular}

This component represents the number of years an employee worked in SPC. Table 3 shows that 14 of the respondents or $21 \%$ have worked less than a year. The data shows that 27 of the employees are from the 1-5 years category representing $39 \%$ of the sample population. It illustrates that the majority of the full-time employees have tenures of less than five years representing $60 \%$ of the sample. The data shows that $40 \%$ of the respondents belong to the rest of the categories, 
almost evenly distributed between $9 \%$ to $11 \%$ for remaining categories.

Table 4. Demographic Profile according to Educational Qualification

\begin{tabular}{|c|c|c|}
\hline Educational Qualification & Frequency & Percentage \\
\hline High School Graduate & 2 & $3 \%$ \\
\hline Bachelor's Degree & 37 & $53 \%$ \\
\hline Master's Degree & 22 & $31 \%$ \\
\hline Professional Degree & 2 & $3 \%$ \\
\hline Doctorate Degree & 7 & $10 \%$ \\
\hline Total & 70 & $100 \%$ \\
\hline
\end{tabular}

At the beginning of the study, educational qualification was also categorized into five categories. The table shows that 2 of the respondent'srepresent $3 \%$ of the sample are from the high school graduate group. The majority of the respondents, 37 full-time employees, 53\%, are bachelor's degree holders. The data further shows that 22 full-time employees, $31 \%$ of the sample population, have master's degree. There are only two who earned professional degrees, and 7 of the remaining respondents or $10 \%$ of the sample have doctorate degrees.

Table 5. Demographic Profile according to Marital Status

\begin{tabular}{|c|c|c|}
\hline Marital Status & Frequency & Percentage \\
\hline Single, never married & 26 & $37 \%$ \\
\hline Married & 40 & $58 \%$ \\
\hline Widowed & 3 & $4 \%$ \\
\hline Separated & 1 & $1 \%$ \\
\hline Total & 70 & $100 \%$ \\
\hline
\end{tabular}

Table 5 shows that there are 26 single, never married full-time employees, 40 married employees, three of the respondents are widowed, and one is separated. Married employees represent $58 \%$ of the sample while the single, never married employees represent $37 \%$ of the total sample. 
Table 6. Demographic Profile according to Employment Status

\begin{tabular}{|c|c|c|}
\hline Employment Status & Frequency & Percentage \\
\hline Regular & 44 & $63 \%$ \\
\hline Probationary & 26 & $37 \%$ \\
\hline Total & 70 & $100 \%$ \\
\hline
\end{tabular}

Table 6 shows that the majority of the respondents are regular employees representing $63 \%$ of the sample population. The remaining 26 full-time employees belong to the Probationary category; this represents $37 \%$ of the sample.

Table 7. Demographic Profile according to Employment Classification

\begin{tabular}{|c|c|c|}
\hline Employment Classification & Frequency & Percentage \\
\hline Department Head/Dean & 12 & $17 \%$ \\
\hline College Faculty & 20 & $29 \%$ \\
\hline Basic Education Faculty & 15 & $21 \%$ \\
\hline Admin/Support Staff & 23 & $33 \%$ \\
\hline Total & 70 & $100 \%$ \\
\hline
\end{tabular}

Table 7 shows the employment classification of the respondents. Full-time employees from the sample who work as Department Heads in the Administrative Department or Deans in the Academic Department totaled 12 employees, representing $17 \%$ of the sample population. Exactly $50 \%$ of the sample is from the faculty, of which $29 \%$ are from the College Faculty while the remaining 15 employees are from the Basic Education Department. Further, the Admin/ Support Staff is comprised of 23 employees of the respondents representing 33\% of the total sample.

Table 8. Demographic Profile according to Salary Rate

\begin{tabular}{|c|c|c|}
\hline Salary Rate & Frequency & Percentage \\
\hline $8,500-13,500 \mathrm{PHP}$ & 45 & $64 \%$ \\
\hline $13,501-18,000 \mathrm{PHP}$ & 16 & $23 \%$ \\
\hline $18,001-23,000 \mathrm{PHP}$ & 4 & $6 \%$ \\
\hline 23,001 PHP or more & 5 & $100 \%$ \\
\hline Total & 70 & $7 \%$ \\
\hline
\end{tabular}


According to the data collected, 45 of those surveyed receive a salary between 8,500-13500 PHP representing 64\% of the sample population. Another 16 full-time employees receive 13,501-18,000 PHP per month, representing an additional $23 \%$ of the sample. The remaining nine full-time employees receive between 18,001 or more, representing $13 \%$ of the sample population.

Table 9. Demographic Profile according to Number of Children

\begin{tabular}{|c|c|c|}
\hline Number of Children & Frequency & Percentage \\
\hline None & 36 & $52 \%$ \\
\hline $1-2$ Children & 24 & $34 \%$ \\
\hline $3-4$ Children & 9 & $13 \%$ \\
\hline 5 -more Children & 1 & $100 \%$ \\
\hline Total & 70 & $1 \%$ \\
\hline
\end{tabular}

The last component of the profile is the number of children the respondent employees have. Table 9 shows 36 of the employees have no children; this represents the majority, making up $52 \%$ of the sample population. The second biggest group in this component is the employees who have 1-2 children, representing $34 \%$ of the sample. The remaining ten employees from the sample have 3 or more children, of which only one has 5 or more children.

Objective 2. To determine the job satisfaction of the employees in relation to work itself, pay, promotion, supervision, co-workers, and the job in general

Table 10. Job Satisfaction of Employees according to Age

\begin{tabular}{|c|c|c|c|c|c|c|c|c|c|}
\hline Age & 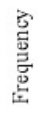 & $\begin{array}{l}\text { Mean/Standard } \\
\text { Deviation (SD) }\end{array}$ & 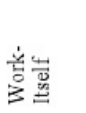 & $\sqrt{5}$ & 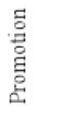 & 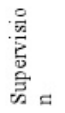 & $\begin{array}{l}\text { 离 } \\
\text { 产 } \\
\text { 咅 }\end{array}$ & 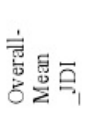 & 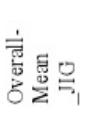 \\
\hline \multirow[b]{2}{*}{$21-29$} & \multirow[t]{2}{*}{23} & Mean & 1.40 & 2.09 & 2.00 & 1.72 & 1.50 & 1.68 & 1.40 \\
\hline & & SD & 0.50 & 0.68 & 0.87 & 0.98 & 0.59 & 0.47 & 0.50 \\
\hline \multirow[b]{2}{*}{$30-39$} & \multirow[t]{2}{*}{18} & Mean & 0.88 & 1.35 & 1.41 & 1.29 & 1.17 & 1.35 & 1.11 \\
\hline & & SD & 0.48 & 0.86 & 0.93 & 0.84 & 0.63 & 0.70 & 0.60 \\
\hline \multirow[b]{2}{*}{$40-49$} & \multirow[t]{2}{*}{16} & Mean & 1.06 & 1.43 & 1.5 & 1.25 & 1.18 & 1.18 & 1.00 \\
\hline & & SD & 0.57 & 0.81 & 0.89 & 0.85 & 0.75 & 0.75 & 0.51 \\
\hline \multirow[b]{2}{*}{$50-59$} & \multirow[t]{2}{*}{7} & Mean & 1.00 & 1.14 & 1.57 & 1.14 & 1.42 & 1.42 & 1.14 \\
\hline & & SD & 0.57 & 0.89 & 0.97 & 0.69 & 0.53 & 0.78 & 0.37 \\
\hline \multirow[b]{2}{*}{$60-69$} & \multirow[t]{2}{*}{6} & Mean & 1.00 & 1.16 & 1.16 & 1.33 & 1.33 & 1.33 & 1.33 \\
\hline & & SD & 0.63 & 0.75 & 0.75 & 0.81 & 0.51 & 0.81 & 0.51 \\
\hline
\end{tabular}


Table 10 shows that the 21-29 years old age group is not satisfied with pay, promotion, supervision, and coworker with mean values higher than 1.49 . This age group is most dissatisfied with pay, and promotion as reflected by mean values of 2.09 and 2.00 respectively. They are, however, satisfied with the job in general with a mean of 1.40 . The standard deviation values of 0.68 and 0.87 for pay and promotion respectively suggest that the responses for promotion have more variability than in pay.

The table also reflects that the employees from the rest of the age categories are satisfied with the different facets except for promotion for the 40-49 years old, and 50-59 years old age brackets where they have mean values of more than 1.49. Employees from all categories are satisfied with work itself and co-worker except for the 21-29 age group (mean $=1.50)$. Further, the results show that the employees from the different age groups are satisfied with job in general with mean values ranging from 1.00 to 1.40 . Their responses for JIG have relatively less variability with standard deviations ranging from 0.37 to 0.60 .

Table 11. Job Satisfaction of Employees according to Gender

\begin{tabular}{|c|c|c|c|c|c|c|c|c|c|}
\hline Gender & $\begin{array}{l}\text { 灾 } \\
\text { 莺 } \\
\text { 总 }\end{array}$ & $\begin{array}{l}\text { Mean/Standard } \\
\text { Deviation (SD) }\end{array}$ & 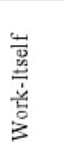 & 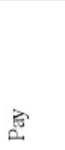 & 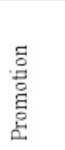 & 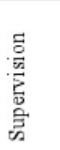 & 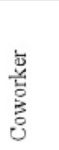 & 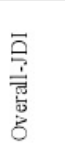 & 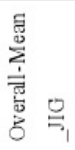 \\
\hline \multirow[b]{2}{*}{ Female } & \multirow[b]{2}{*}{51} & Mean & 1.06 & 1.56 & 1.56 & 1.46 & 1.3 & 1.38 & 1.18 \\
\hline & & SD & 0.58 & 0.88 & 0.97 & 0.99 & 0.67 & 0.72 & 0.56 \\
\hline \multirow[b]{2}{*}{ Male } & \multirow[b]{2}{*}{19} & Mean & 1.29 & 1.64 & 1.82 & 1.29 & 1.41 & 1.58 & 1.29 \\
\hline & & SD & 0.46 & 0.78 & 0.72 & 0.46 & 0.50 & 0.50 & 0.46 \\
\hline
\end{tabular}

${ }^{* *}$ Mean < 1.50: Satisfied

${ }^{* *}$ Mean $>1.49$ : Not Satisfied

Table 11 shows that the female respondents are satisfied with work itself, supervision, and co-worker with mean scores of less than 1.5. They are most satisfied with the facet coworker $($ mean $=1.06)$. The female employees scored a mean score of 1.56 for pay and 1.56 for promotion indicating dissatisfaction. The standard deviation of 0.88 for pay and 0.97 for promotion point out that their responses are relatively scattered or spread out. Their mean score of 1.38 for the overall mean for the JDI indicates that they are satisfied overall. The female group has a mean score of 1.18 for JIG signifying overall job satisfaction.

The table further demonstrates that the male respondents are satisfied with work itself, supervision, and co-worker with mean scores of less than 1.5 for 
these facets. They are however not satisfied with pay, and promotion as reflected in their mean values of more than 1.49. Further, they are not satisfied with their overall JDI as shown by their mean score of 1.58 . The male group, however, is satisfied with the job in general (mean $=1.29)$. The standard deviations for the overall JDI and JIG of 0.50 and 0.46 respectively indicate that they have relatively less variability in their responses.

\section{Table 12. Job Satisfaction of Employees according to Educational Qualification}

\begin{tabular}{|c|c|c|c|c|c|c|c|c|c|}
\hline $\begin{array}{l}\text { Educational } \\
\text { Classification }\end{array}$ & 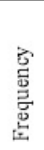 & $\begin{array}{l}\text { Mean/Standard Deviation } \\
\text { (SD) }\end{array}$ & 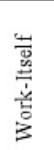 & 空 & 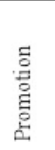 & 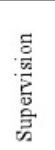 & 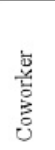 & 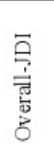 & 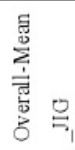 \\
\hline \multirow[b]{2}{*}{ HS Graduate } & \multirow[b]{2}{*}{2} & Mean & 1.50 & 1.00 & 1.50 & 1.00 & 2.00 & 1.50 & 1.00 \\
\hline & & SD & 0.70 & 0.00 & 0.70 & 0.00 & 0.00 & 0.70 & 0.00 \\
\hline \multirow[b]{2}{*}{ Bachelor's Degree } & \multirow[b]{2}{*}{37} & Mean & 1.10 & 1.59 & 1.64 & 1.48 & 1.35 & 1.43 & 1.21 \\
\hline & & SD & 0.51 & 0.79 & 0.91 & 0.93 & 0.58 & 0.60 & 0.47 \\
\hline \multirow[b]{2}{*}{ Master's Degree } & \multirow[b]{2}{*}{22} & Mean & 1.20 & 1.85 & 1.90 & 1.55 & 1.35 & 1.60 & 1.30 \\
\hline & & SD & 0.61 & 0.87 & 0.91 & 0.88 & 0.74 & 0.75 & 0.65 \\
\hline \multirow[b]{2}{*}{ Professional Degree } & \multirow[b]{2}{*}{2} & Mean & 1.24 & 1.18 & 1.24 & 1.24 & 1.24 & 1.24 & 1.24 \\
\hline & & SD & 0.70 & 0.76 & 0.70 & 0.70 & 0.70 & 0.70 & 0.70 \\
\hline \multirow[b]{2}{*}{ Doctorate Degree } & \multirow[b]{2}{*}{7} & Mean & 1.00 & 1.28 & 1.00 & 1.00 & 1.14 & 1.14 & 1.14 \\
\hline & & SD & 0.57 & 0.75 & 0.57 & 0.57 & 0.37 & 0.69 & 0.37 \\
\hline
\end{tabular}

* Mean < 1.50: Satisfied

**Mean > 1.49: Not Satisfied

Table 12 shows the employees from the HS Graduate category are not satisfied with work itself, promotion, and coworker. The two respondents are most dissatisfied with their coworker as reflected by the mean value of 2.00 for this facet. The results indicate that they are satisfied with pay, and supervision both with mean values of 1.00 . They are satisfied with the job in general as reflected in their mean score of 1.00 .

The respondents from the Bachelor's Degree category are not satisfied with pay, promotion, and supervision as reflected by their mean values of more than 1.49. The employees from the Master's Degree category are not satisfied with pay, promotion, and supervision with mean values greater than 1.49 . The responses from both age groups, however, reflected relatively high variability with standard deviation values ranging from 0.79 to 0.93 ; this means that although some of the employees are highly dissatisfied with these facets, many are also highly satisfied 
with pay, promotion, and supervision.

The employees with professional and doctorate degrees are satisfied with work itself, pay, promotion, supervision, and coworker. Lastly, all full-time employees from all the categories are satisfied with the job in general with mean values ranging from 1.00 to 1.30 .

Table 13. Job Satisfaction of Employees according to Marital Status

\begin{tabular}{|c|c|c|c|c|c|c|c|c|c|}
\hline $\begin{array}{l}\text { Marital } \\
\text { Status }\end{array}$ & 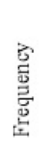 & $\begin{array}{l}\text { Mean/Standard } \\
\text { Deviation (SD) }\end{array}$ & 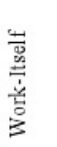 & 空 & 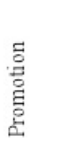 & 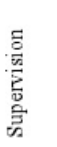 & 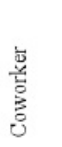 & 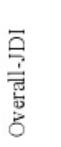 & 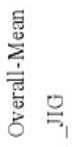 \\
\hline \multirow[b]{2}{*}{ Single } & \multirow[b]{2}{*}{26} & Mean & 1.32 & 1.92 & 1.88 & 1.60 & 1.40 & 1.56 & 1.28 \\
\hline & & $\mathrm{SD}$ & 0.47 & 0.70 & 0.83 & 0.91 & 0.57 & 0.50 & 0.45 \\
\hline \multirow[b]{2}{*}{ Married } & \multirow[b]{2}{*}{40} & Mean & 1.00 & 1.41 & 1.51 & 1.30 & 1.25 & 1.35 & 1.12 \\
\hline & & $\mathrm{SD}$ & 0.56 & 0.88 & 0.94 & 0.86 & 0.67 & 0.74 & 0.57 \\
\hline \multirow[b]{2}{*}{ Separated } & \multirow[b]{2}{*}{1} & Mean & 1.00 & 1.00 & 1.00 & 1.00 & 1.00 & 1.00 & 1.00 \\
\hline & & SD & - & - & - & - & - & - & - \\
\hline \multirow[b]{2}{*}{ Widowed } & \multirow[b]{2}{*}{3} & Mean & 1.00 & 1.00 & 1.00 & 1.33 & 1.66 & 1.33 & 1.66 \\
\hline & & $\mathrm{SD}$ & 1.00 & 1.00 & 1.00 & 1.15 & 0.57 & 1.15 & 0.57 \\
\hline
\end{tabular}

${ }^{* *}$ Mean $<1.50$ : Satisfied

$*$ Mean >1.49: Not Satisfied

Table 13 shows that employees from the Single category are not satisfied with pay, promotion, and supervision. They are most dissatisfied with pay (mean = $1.92)$, followed by promotion $($ mean $=1.88)$, and supervision $($ mean $=1.60)$. Their responses to these facets are relatively dispersed, especially their responses to supervision as shown by a standard deviation value of 0.91 . This means that although some of the employees are highly dissatisfied with these facets, many are also highly satisfied with pay, promotion, and supervision.

The employees from all the other categories are satisfied with work itself, pay, promotion, supervision, and coworker except for the married employees who are not satisfied with promotion (mean $=1.51$ ) and the employees from the widowed category who are not satisfied with coworker (mean=1.66). Interestingly, the employees from the widowed category are not satisfied with job in general (mean=1.66) while the employees from the rest of the categories are satisfied with job in general as shown by the mean values ranging from 1.00 to 1.28. Also, the responses on the JIG are relatively less spread out as reflected by the standard deviation values ranging from 0.45 to 0.57 . 
Table 14. Job Satisfaction of Employees according to Employment Status

\begin{tabular}{|c|c|c|c|c|c|c|c|c|c|}
\hline $\begin{array}{l}\text { Employment } \\
\text { Status }\end{array}$ & 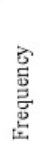 & $\begin{array}{l}\text { Mean/Standard } \\
\text { Deviation (SD) }\end{array}$ & 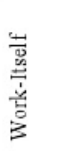 & 空 & 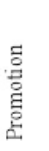 & 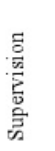 & $\begin{array}{l}\text { 离 } \\
\text { 产 } \\
\text { 总 }\end{array}$ & 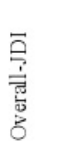 & 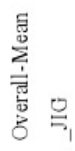 \\
\hline \multirow[b]{2}{*}{ Regular } & \multirow[b]{2}{*}{46} & Mean & 1.07 & 1.47 & 1.51 & 1.47 & 1.40 & 1.40 & 1.23 \\
\hline & & SD & 0.51 & 0.80 & 0.80 & 0.86 & 0.62 & 0.70 & 0.53 \\
\hline \multirow[b]{2}{*}{ Probationary } & \multirow[b]{2}{*}{24} & Mean & 1.17 & 1.78 & 1.86 & 1.30 & 1.21 & 1.47 & 1.17 \\
\hline & & SD & 0.65 & 0.90 & 1.05 & 0.97 & 0.67 & 0.66 & 0.57 \\
\hline
\end{tabular}

Table 14 illustrates that probationary employees are not satisfied with pay and promotion with mean values of 1.78 and 1.86 respectively. Their responses to these two facets are relatively high in variability as shown by the standard deviation value of 0.80 ; this means that although some of the employees from the probationary category are highly dissatisfied with pay, and promotion, many are also highly satisfied with pay, and promotion. The results also point out that the probationary employees are most satisfied with work itself (mean $=1.17)$, having the least mean value compared to the other facets.

The regular employees, who make up the majority of the respondents, are dissatisfied with promotion only, with a mean value of 1.51 .They are satisfied with work itself, pay, supervision, and coworker. They are least satisfied with pay, and supervision both with mean values of 1.47 . The standard deviation values of 0.80 and 0.86 for pay and supervision indicate a relatively high variability in their responses. This means that many of the regular employees are highly satisfied and at the same time a considerable number of regular employees are also highly dissatisfied with pay and supervision. Also, regular employees are most satisfied with work itself $($ mean $=1.07)$ a significant having the least mean value compared to the other facets.

Both regular $($ mean $=1.23)$ and probationary $($ mean=1.17) employees are satisfied with the job in general with relatively less variability in their responses as reflected by their standard deviations of 0.53 , and 0.57 respectively. 
Table 15. Job Satisfaction of Employees according to Employment Classification

\begin{tabular}{|c|c|c|c|c|c|c|c|c|c|}
\hline $\begin{array}{l}\text { Employment } \\
\text { Classification }\end{array}$ & $\begin{array}{l}\text { 灾 } \\
\text { 总 } \\
\text { 总 }\end{array}$ & $\begin{array}{l}\text { Mean/Standard } \\
\text { (SD) }\end{array}$ & 咅荘 & 醇 & $\begin{array}{l}\text { : } \\
\text { 总 } \\
\vdots \\
\text { 怘 }\end{array}$ & 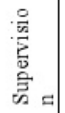 & $\begin{array}{l}\text { 离 } \\
\text { 产 } \\
\text { ن }\end{array}$ & $\begin{array}{l}\overrightarrow{\bar{z}} \\
\dot{3} \\
\dot{3}\end{array}$ & 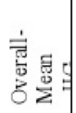 \\
\hline \multirow[b]{2}{*}{ Department Head/Dean } & \multirow[b]{2}{*}{12} & Mean & 1.08 & 1.50 & 1.50 & 1.41 & 1.25 & 1.50 & 1.08 \\
\hline & & $\mathrm{SD}$ & 0.28 & 0.52 & 0.67 & 0.51 & 0.45 & 0.52 & 0.28 \\
\hline \multirow[b]{2}{*}{ College Faculty } & \multirow[b]{2}{*}{20} & Mean & 1.27 & 1.83 & 1.88 & 1.55 & 1.44 & 1.55 & 1.38 \\
\hline & & SD & 0.75 & 0.98 & 1.13 & 1.14 & 0.78 & 0.85 & 0.69 \\
\hline \multirow[b]{2}{*}{ Basic Education Faculty } & \multirow[b]{2}{*}{15} & Mean & 1.00 & 1.40 & 1.60 & 1.46 & 1.33 & 1.33 & 1.13 \\
\hline & & SD & 0.65 & 0.98 & 0.98 & 1.06 & 0.81 & 0.72 & 0.63 \\
\hline \multirow[b]{2}{*}{ Administrative Staff } & \multirow[b]{2}{*}{23} & Mean & 1.08 & 1.52 & 1.47 & 1.26 & 1.26 & 1.34 & 1.17 \\
\hline & & $\mathrm{SD}$ & 0.41 & 0.79 & 0.79 & 0.68 & 0.44 & 0.57 & 0.38 \\
\hline
\end{tabular}

Table15 shows the employees from the different employment classifications are not satisfied with pay except for the employees belonging to the Basic Education Department (mean=1.40). The employees from the College Faculty group is the most dissatisfied with pay (mean $=1.83$ ) compared to the mean values of 1.50, and 1.52 for the Department Head/Dean and the Admin Staff categories. The responses of the College Faculty group for pay are relatively high in variability as indicated by the standard deviation value of 0.98 . This means that although some of employees from the College Faculty are highly dissatisfied with pay, many employees in the same group are also highly satisfied with pay.

The employees from the Department Head/Dean, College Faculty, and Admin Staff categories are not satisfied with promotion as reflected by their respective mean values of $1.50,1.88$, and 1.60. Further, the employees from all the categories are satisfied with work itself, supervision, and coworker except for the College Faculty category who are not satisfied with supervision, and coworker as reflected by both their mean values equal to 1.55 . Lastly, employees from all the categories are satisfied with the job in general as indicated by their mean values ranging from 1.08 to 1.38 . Of all the responses for JIG from the different categories, the responses from the Department Head/Dean group has the least variability $(S D=0.28)$; this signifies that their responses are closer to the mean value for JIG. 
Table 16. Job Satisfaction of Employees according to Salary Rate

\begin{tabular}{|c|c|c|c|c|c|c|c|c|c|}
\hline Salary Rate & 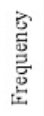 & Mean/Standard Deviation (SD) & 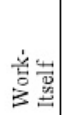 & 焉 & 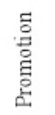 & $\begin{array}{l}\text { 量 } \\
\text { 总 } \\
\text { 窝 }\end{array}$ & 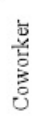 & $\begin{array}{l}\text { 言 } \\
\text { 总宣 }\end{array}$ & 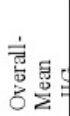 \\
\hline \multirow[t]{2}{*}{$8,500-13,500$ PHP } & \multirow[b]{2}{*}{45} & Mean & 1.13 & 1.64 & 1.64 & 1.42 & 1.35 & 1.44 & 1.17 \\
\hline & & $\mathrm{SD}$ & 0.57 & 0.86 & 0.90 & 0.91 & 0.64 & 0.65 & 0.53 \\
\hline \multirow[t]{2}{*}{$13,501-18,000$ PHP } & \multirow[b]{2}{*}{16} & Mean & 1.25 & 1.62 & 1.92 & 1.71 & 1.42 & 1.64 & 1.50 \\
\hline & & SD & 0.48 & 0.81 & 0.91 & 0.82 & 0.64 & 0.63 & 0.51 \\
\hline \multirow[t]{2}{*}{$18,001-23,000 \mathrm{PHP}$} & \multirow[t]{2}{*}{4} & Mean & 1.27 & 1.00 & 1.27 & 1.00 & 1.00 & 1.00 & 1.00 \\
\hline & & SD & 0.57 & 1.00 & 0.57 & 1.00 & 0.00 & 1.00 & 0.00 \\
\hline \multirow[t]{2}{*}{23,001 PHP or more } & \multirow[b]{2}{*}{5} & Mean & 1.00 & 1.40 & 1.40 & 1.00 & 1.20 & 1.20 & 1.00 \\
\hline & & SD & 0.00 & 0.57 & 0.54 & 0.00 & 0.44 & 0.44 & 0.00 \\
\hline
\end{tabular}

As seen in Table 16, employees who receive between 8,500-18,000 PHP are dissatisfied with pay and promotion with mean values for these facets ranging from 1.62 to 1.92 . A mean value for pay of 1.92 indicates that the employees from the 13,501-18,000 PHP are the most dissatisfied. Their responses are relatively highly variable as reflected by the standard deviation values ranging from 0.81 to 0.91 . This means that although some of the employees are highly dissatisfied with pay, and promotion, many are also highly satisfied with pay, and promotion.

The employees from all the categories are satisfied with work itself, supervision, and coworker except for the employees from the 13,501-18,000 PHP category who are dissatisfied with supervision (mean=1.71). Lastly, only the employees from the 13,501-18,000 PHP category are dissatisfied with the job in general (mean $=1.50$ ), the majority of the employees from the other categories are satisfied with job in general with mean values ranging from 1.00 to 1.17 .

Table 17. Job Satisfaction of Employees according to Number of Children

\begin{tabular}{|c|c|c|c|c|c|c|c|c|c|}
\hline Number of Children & 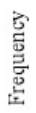 & Mean/Standard Deviation (SD) & 亲 & 롬 & 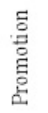 & 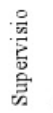 & ن & $\begin{array}{l}\dot{\bar{z}} \\
\text { 峞 }\end{array}$ & 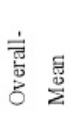 \\
\hline \multirow[t]{2}{*}{ No Children } & \multirow[b]{2}{*}{36} & Mean & 1.28 & 1.71 & 1.74 & 1.60 & 1.40 & 1.51 & 1.28 \\
\hline & & $\mathrm{SD}$ & 0.57 & 0.78 & 0.88 & 0.88 & 0.65 & 0.65 & 0.51 \\
\hline \multirow[b]{2}{*}{ 1-2 Children } & \multirow[b]{2}{*}{24} & Mean & 0.90 & 1.45 & 1.63 & 1.22 & 1.22 & 1.36 & 1.13 \\
\hline & & $\mathrm{SD}$ & 0.42 & 0.80 & 0.95 & 0.86 & 0.61 & 0.65 & 0.56 \\
\hline \multirow[b]{2}{*}{ 3-4 Children } & \multirow[b]{2}{*}{9} & Mean & 1.00 & 1.11 & 1.11 & 1.11 & 1.22 & 1.11 & 1.00 \\
\hline & & SD & 0.70 & 1.05 & 0.92 & 0.92 & 0.66 & 0.78 & 0.50 \\
\hline \multirow[b]{2}{*}{5 or more Children } & \multirow[b]{2}{*}{1} & Mean & 1.00 & 2.00 & 1.00 & 2.00 & 1.00 & 2.00 & 1.00 \\
\hline & & $\mathrm{SD}$ & - & - & - & - & - & - & - \\
\hline
\end{tabular}

** Mean > 1.49: Not Satisfied 
Table 17 shows that employees from the No Children category are not satisfied with pay, promotion, and supervision with mean values higher than 1.49 . The employees from this category are most dissatisfied with promotion (mean=1.74). They are satisfied with the job in general with a mean of 1.28. The standard deviation values ranging from 0.78 to 0.88 for pay, promotion, and supervision indicate that their responses to these facets are relatively high in variability. This means that although some of the employees are highly dissatisfied with these facets, many are also highly satisfied with pay, promotion, and supervision.

The table also reflects that the employees from the 1-2 Children category are satisfied with work itself, pay, supervision, and coworker but are dissatisfied with promotion $($ mean $=1.63)$. The employees from the 3-4 of Children category are satisfied with the all the facets with mean values ranging from 1.0 to 1.22. Further, the lone respondent from the 5 or more Children category is dissatisfied with pay, and supervision while satisfied with work itself, promotion, and coworker. Lastly, the table shows that employees from all categories are satisfied with the job in general with mean values ranging from 1.00 to 1.28.

Table 18. Overall Job Satisfaction of Employees as Measured by JDI and JIG

\begin{tabular}{|c|c|c|c|}
\hline Overall Job Satisfaction & $\mathrm{N}$ & Mean & Std. Deviation \\
\hline Job Descriptive Index (JDI) & 70 & 1.4348 & 0.67472 \\
\hline Job In General (JIG) & 70 & 1.2029 & 0.53081 \\
\hline
\end{tabular}

Table 18 shows the overall job satisfaction of the employees measured by the Job Descriptive Index (JDI) overall mean and the overall mean for Job In General (JIG). The full-time employees are satisfied with their jobs as measured both by JDI (mean $=1.43)$ and JIG (mean $=1.20)$. The standard deviation of 0.67 for JDI means that the responses of the employees on JDI has relatively more variability compared to the responses to JIG (SD=0.53).

\section{Objective 3. To determine if there is a significant relationship between} the employees' profile and their job satisfaction as measured by the Job Descriptive Index

The researchers looked into the association between the demographic profile of the employees and their responses on the job satisfaction survey. The table below shows the relationship. 
Table 19. The Relationship between Demographic Profile and Job Satisfaction as Measured by the Job Descriptive Index (JDI)

\begin{tabular}{|c|c|c|c|}
\hline Profile & Chi square- value & p-value & Remarks \\
\hline Age & 13.64 & 0.32 & Not significant \\
\hline Gender & 4.30 & 0.63 & Not Significant \\
\hline Length of Service & 16.68 & 0.33 & Not Significant \\
\hline $\begin{array}{c}\text { Educational } \\
\text { Qualification }\end{array}$ & 11.25 & 0.50 & Not Significant \\
\hline Marital Status & 9.08 & 0.43 & Not Significant \\
\hline Employment Status & 2.20 & 0.90 & Not Significant \\
\hline $\begin{array}{c}\text { Employment } \\
\text { Classification }\end{array}$ & 11.15 & 0.26 & Not Significant \\
\hline Salary Rate & 11.16 & 0.26 & Not Significant \\
\hline Number of Children & 4.80 & 0.85 & Not Significant \\
\hline
\end{tabular}

\section{Objective 4. To determine if there is a significant relationship between} the employees' profile and their job satisfaction as measured by the Job In General

A Chi-Square test analyzing the categories under each demographic profile against the employees opinion on job satisfaction as measured by the Job Descriptive Index yielded chi-square values ranging from 2.20 (employment status) to 16.68 (length of service) and p-values ranging from 0.26 (salary rate) to 0.90 (employment status). Since the p-values are all more than the 0.05 level of significance, as shown in Table 19, the researcher failed to reject the null hypothesis, H01. There is no evidence that there is a relationship between the employees' demographic profile and their job satisfaction as measured by the Job Descriptive Index.

Table 20. The Relationship between Demographic Profile and Job Satisfaction as Measured by the Job In General (JIG)

\begin{tabular}{|c|c|c|c|}
\hline Profile & Chi square- value & p-value & Remarks \\
\hline Age & 8.44 & 0.39 & Not significant \\
\hline Gender & 1.96 & 0.48 & Not Significant \\
\hline Length of Service & 15.97 & 0.10 & Not Significant \\
\hline Educational Qualification & 13.07 & 0.10 & Not Significant \\
\hline Marital Status & 6.01 & 0.42 & Not Significant \\
\hline Employment Status & 0.92 & 0.92 & Not Significant \\
\hline $\begin{array}{c}\text { Employment } \\
\text { Classification }\end{array}$ & 14.39 & 0.02 & Significant \\
\hline Salary Rate & 8.35 & 0.21 & Not Significant \\
\hline \begin{tabular}{c} 
Number of Children \\
\hline
\end{tabular} & 3.22 & 0.78 & Not Significant \\
\hline
\end{tabular}




\section{Objective 5. To determine if there is a significant difference between the demographic profile of the employees and their job satisfaction as measured by the Job Descriptive Index}

A Chi-Square test analyzing the categories under each demographic profile against the employees opinion on job satisfaction as measured by the Job In General yielded chi-square values ranging from 0.92 (employment status) to 15.97 (length of service) and p-values ranging from 0.02 (employment classification) to 0.92 (employment status). Since the p-value of employment classification (0.02) is more than the 0.05 level of significance, as shown in Table 20, the researcher rejected the null hypothesis, H02. There is a significant relationship between the employees' demographic profile and their job satisfaction as measured by the Job In General (JIG).

Table 21. The Mean Difference between Demographic Profile and Job Satisfaction as Measured by the Job Descriptive Index (JDI)

\begin{tabular}{|c|c|c|c|}
\hline $\begin{array}{c}\text { Sources of Variation } \\
\text { Between Groups }\end{array}$ & F & p-value & Remarks \\
\hline Age & 1.39 & 0.24 & Not significant \\
\hline Gender & 0.79 & 0.45 & Not Significant \\
\hline Length of Service & 0.51 & 0.76 & Not Significant \\
\hline Educational Qualification & 1.64 & 0.17 & Not Significant \\
\hline Marital Status & 0.59 & 0.62 & Not Significant \\
\hline Employment Status & 0.42 & 0.65 & Not Significant \\
\hline $\begin{array}{c}\text { Employment } \\
\text { Classification }\end{array}$ & 0.45 & 0.71 & Not Significant \\
\hline $\begin{array}{c}\text { Salary Rate } \\
\text { Number of Children }\end{array}$ & 1.11 & 0.34 & Not Significant \\
\hline
\end{tabular}

One Way-ANOVA and t-test were used to analyze the difference between each category's mean value from each demographic profile against employees opinion on job satisfaction as measured by the Job Descriptive Index (JDI); this yielded F values ranging from 0.42 (employment status) to 1.64 (educational qualification) and p-values ranging from 0.17 (educational qualification) to 0.76 (length of service). Since the p-values are all more than the 0.05 level of significance, as shown in Table 21, the researcher accepted the null hypothesis, H03. There is 
no significant mean difference between the employees' demographic profile and their job satisfaction as measured by the Job Descriptive Index.

\section{Objective 6. To determine if there is a significant difference between the} demographic profile of the employees and their job satisfaction as measured by the Job In General

Table 22. The Mean Difference between Demographic Profile and Job Satisfaction as Measured by the Job In General (JIG)

\begin{tabular}{|c|c|c|c|}
\hline $\begin{array}{c}\text { Sources of Variation } \\
\text { Between Groups }\end{array}$ & F & p-value & Remarks \\
\hline Age & 1.68 & 0.16 & Not significant \\
\hline Gender & 0.61 & 0.43 & Not Significant \\
\hline Length of Service & 2.07 & 0.08 & Not Significant \\
\hline Educational Qualification & 1.14 & 0.34 & Not Significant \\
\hline Marital Status & 1.24 & 0.30 & Not Significant \\
\hline Employment Status & 0.17 & 0.83 & Not Significant \\
\hline $\begin{array}{c}\text { Employment } \\
\text { Classification }\end{array}$ & 1.03 & 0.38 & Not Significant \\
\hline Salary Rate & 2.04 & 0.11 & Not Significant \\
\hline Number of Children & 0.88 & 0.45 & \\
\hline
\end{tabular}

One Way-ANOVA and t-test was used to analyze the difference between each category's mean values from each demographic profile against employee's opinion on job satisfaction as measured by the Job In General (JIG); this yielded F values ranging from 0.17 (employment status) to 2.07 (length of service) and p-values ranging from 0.08 (length of service) to 0.83 (employment status). Since the p-values are all more than the 0.05 level of significance, as shown in Table 22, the researcher accepted the null hypothesis, H04. There is no significant mean difference between the employees' demographic profile and their job satisfaction as measured by the Job In General.

\section{CONCLUSIONS}

In general, the majority of full-time employees are not satisfied with pay, and promotion. Also, a considerable number of employees are not satisfied with 
supervision. These dissatisfiers if not minimized will continue to serve as a source of job dissatisfaction. The results of this study validated the reasons why SPC experienced a relatively high employee turnover for the last five years. The study is evident, however, that employees are satisfied with work itself, a motivator. More importantly, the full-time employees are satisfied with the job in general, a global measure of job satisfaction. The measure of their job satisfaction is at the higher end of the JIG scale (mean=1.20), this means that the employees are satisfied with their job even though they are not satisfied with some dissatisfiers like pay, promotion, and supervision. The employees' overall satisfaction with their job implies that management is strong in recognizing achievements, gives responsibility for enlarged tasks, and provides growth and advancement to higher level tasks and other motivators that result in the overall employees' job satisfaction.

\section{RECOMMENDATIONS}

1. Management should carry out the proposed tuition fee increase for SY 2016-17. Of the total tuition fee increase, 70\% will be used for the increase in salary and benefits for the employees.

2. The HR Office should update the salaries benchmarked five years ago from the different private colleges in Iligan City as well as private companies that employ engineers.

3. The data on salaries is for the planning and updating of the salary and benefits structure of the school for the next five years.

4. Management should provide more opportunities for the employees to move up the ranks. Providing more opportunities include increasing the budget for faculty and staff development programs.

5. Management should provide more training and workshops on topics of supervision and management for school officials to improve their management and supervision skills.

6. Further researches in line with job satisfaction are recommended for study: Job satisfaction and absenteeism and job satisfaction and work performance. 


\section{LITERATURE CITED}

Adams, J.S. (1965). Inequity in social exchange. In L. Berkowitz(ed), Advances in experimental social psychology. New York: Academic Press.

Alderfer, C. (1969). An empirical test of a new theory of human needs. Organizational behavior and human performance, I, 142-175.

Bogler, R., \& Nir, A. E. (2012). The importance of teachers' perceived organizational support to job satisfaction. Journal of Educational Administration, 50(3), 287-306. Retrieved fromhttp://dx.doi.org/ $10.1108 / 09578231211223310$

Cherry, K. (2015). Hierarchy of needs. The five levels of Maslow's hierarchy of needs. Retrieved from; http://psychology.about.com/od/theories ofpersonality/a/hierarchyneeds.htm

CHED accreditation in the Philippines (n.d.). Retrieved from http:// stlinusonlineinstitute.com/yahoo_site_admin/assets/docs /CHED_ACCREDITA

Herzberg, F. (1974a). Economic crisis and work motivation. Industry Week, $180(8), 54$.

Ingersoll, R.M. (2001). Teacher turnover and teacher shortages: An organizational analysis. American Educational Research Journal, 38(3), 499 -534.

Maslow, A. (1954). Motivation and personality. New York: Harper \& Row.

McLeod, S. (2014). Maslow's hierarchy of needs. Retrieved from: http:// www.simplypsychology.org/maslow.html

Redmond, B. (2015). Equity theory. Retrieved from; https://wikispaces.psu.edu /display/PSYCH484/5.+Equity+Theory 
Shaikh, M. \& Bhutto, N. (2012). Facets of job satisfaction and its association with Performance International Journal of Business and Social Science Vol. 3 No. 7.

Stello C. . Herzberg's (n.d.). Two-factor theory of job satisfaction: An integrative literature review. Department of organizational leadership, policy, and development college of education and human development University of Minnesota. Retrieved from http://www.cehd.umn.edu/ olpd/research/studentconf/2011/stelloherzberg.pdf https:// www.mindtools.com/pages/article/newTMM_78.htm

Theory x theory y (2008). The economist web site Retrieved from; http://www. economist.com/node/12370445

Theory X \& Theory Y: Two Types of Managers. (n.d.). Retrieved from http:// study.com/academy/lesson/theory-x-theory-y-two-types-of-managers. html

Seron, C. (2007). The status of legal professionalism at the close of the twentieth century: Chicago lawyers and urban lawyers. Law \& social inquiry, 32(2), 581-607.

Seegmiller, J.G. (2006). Perceptions of quality for graduate athletic training education. Journal of Athletic Training, 41(4), 415-21. Retrieved from http://search.proquest.com/docview/206649668?accountid=139409

Zickar, M. (n.d.). Job Description Index. Bowling Green State University. Retrieved fromhttps://www.bgsu.edu/arts-and-sciences/psychology /services/job-descriptive-Index.html 